\title{
Digital Marketing Communications for Sustainable Company Development
}

\author{
Natalya Izakova*, Larisa Kapustina, Elizaveta Makovkina, Kseniya Elkina \\ Ural State University of Economics, Yekaterinburg, Russia \\ *Corresponding author.Email: izakovan@gmail.com
}

\begin{abstract}
Companies' sustainable development requires the use of digital marketing communications as the most effective means of interaction with the consumer. The article presents the method of selecting digital marketing communications based on the Rossiter-Percy matrix method. The study analyses the features of different approaches to the development of a communication strategy, sets out the main principles and stages of the development of the company's communication strategy. The proposed methodology allows connecting the motivation and involvement of consumers in the purchase process with the choice of a set of marketing communications. The results of the authors' study recommend the use contextual advertising, search optimization of the site, running contests on social networks, placing banners and teasers on thematic and popular portals, posting news articles, recipes, information about participation and victories in industry competitions on the company's site and other industry media.
\end{abstract}

Keywords: digital marketing communications, resilient communication infrastructure, communication strategy.

\section{INTRODUCTION}

For business, building a special, trusting relationship with consumers is a key task. Active communication in order to demonstrate to consumers the benefits of mutual cooperation forms a positive image and desire to cooperate with the company in the future. One of the objectives of a sustainable economy is to build sustainable infrastructure, promote inclusive and sustainable industrialization and innovation. The external environment has a direct impact on the sustainable development of companies that form the structure of a sustainable economy. The coronovirus pandemic has made a significant contribution to the global digital transformation of business and communications. Now more than half of the world's population is connected to the Internet, and almost the entire world's population is exploiting a mobile network. Companies are forced to increase the usage of information and communication technologies due to the transition to remote operation and the need to provide digital access to basic goods and services. The stability of the communication infrastructure primarily implies the availability of information to the consumer about the company's activities, the quality and features of products and services, the ability to quickly feedback and solve problems. Marketing communication is the company's activity that establishes relationships with all participants in the marketing environment for successful and sustainable work in the long term. In turn, the effectiveness of communication policy is manifested in the synergistic effect of using several marketing communication tools at the same time.

Despite the fact that there is a clear trend towards a strategic approach in the management of marketing communications, methods have not yet been developed to minimize risks in the development and implementation of the strategy. The transition to digital communications increases the "power" of mutual communication, gives the opportunity to control the process of communication to all participants, and makes it possible to communicate both on an individual, group and intergroup level [1]. Digital communication channels and tools include an organization's website, search engine optimization (SEO), contextual advertising, social media, video hosting, email marketing, mobile applications. Digital marketing communications help the company collaborate with customers to create and deliver value together, reduce information asymmetries between a customer and a company, and transform a company's product into a digital service product [2]. 
The relevance of the study is determined by the fact that the attitude of consumers to the brand and the awareness of the target audience about the brand should underlie the development of a communication strategy. The purpose of this study is to develop a methodology for selecting digital marketing communications based on the Rossiter-Percy matrix method and testing them for the bread-baking complex. To achieve this goal, the following objectives were met: the peculiarities of the existing approaches to the development of the company's communication strategy are described, the general principles and main stages of the development of the company's communication strategy are identified, and digital marketing tools of the communication strategy for the bread-baking complex are systematized. The methodological basis of the study was compiled by a systematic approach, expert methods of scientific research, including a questionnaire survey.

Interpretations of the term "communication strategy" are based on selected objectives, principles and types of communication, long-term plans integrated with the company's overall strategy [3]. J. Landrevi, D. Lyndon and J. Levy see the company's communication strategy as a combination of various signals and information messages that the organization itself distributes to a target audience or a certain segment of the population [4]. The issues of the influence of digital marketing communications on the process of making a purchase decision by consumers are considered in the works of many researchers $[5,6,7,8]$. The importance of the number of communication tools with the consumer and the content that is communicated to the consumer is discussed in the works of Bronnenberg B. J., Kim B. J. and Mela C. F. [9].

To select communication tools between the brand and its target audience, the Foot-Cown-Belding matrix can be used. Its essence is a necessity to focus on its product category and product features promoting a company's product [10]. At the same time, this method does not take into consideration such parameters as brand recognition and consumer attitudes. A more comprehensive approach is the Rossiter-Percy methodology, which takes into account both the consumer's attitude to the company's trademark and awareness of it [11].

\section{MATERIALS AND METHODS}

Initially, the Rossiter-Percy method was proposed to solve brand awareness issues and form an attitude towards it. However, the authors believe that it can be applied at each stage of the development of a communication strategy and the selection of digital marketing communications tools, since it is based on an assessment of the purchase motivation, that is, the problem for the solution of which the consumer must be interested in the brand and decide on its purchase. Developing a communication strategy based on solving consumer problems is the most appropriate marketing approach in doing business. The methodology for selecting digital marketing communications based on the Rossiter-Percy matrix method, proposed by the authors, is presented in Figure 1.

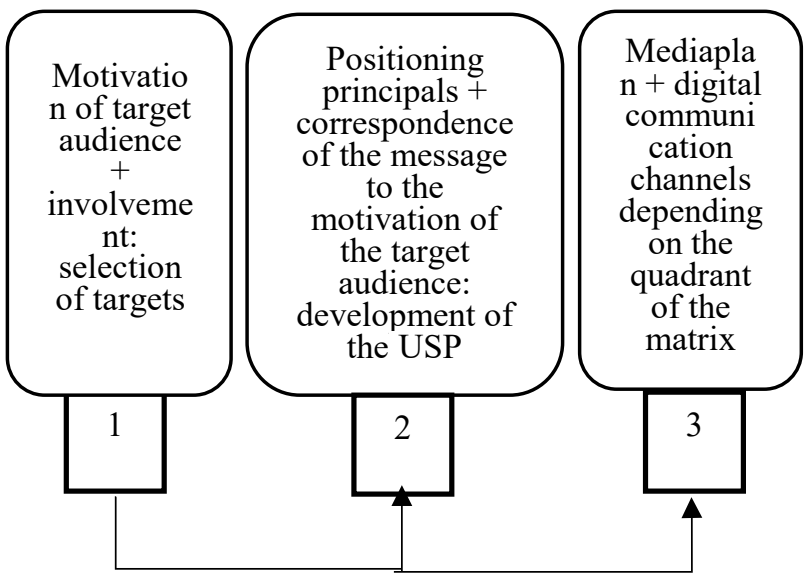

Figure 1 Methodology of selection digital marketing communications based on the Rossiter-Percy matrix method

At the first stage, using the matrix, it is necessary to determine the reasons that encourage the consumer to make a purchase (motivation) and the prerequisites for making a purchase decision (involvement). Further, in order to determine the general principles of product positioning in the market, we analyze for the information message and the selected communication channel of the closest competitors. The result of the second stage is the development of a unique selling proposition (USP). At the last stage, communication channels are selected for transmission of the USP to the target audience depending on the square of the Rossiter-Percy matrix.

According to the Rossiter-Percy matrix, understanding the motivation for the purchase, the company can choose the strategic goal of the communication strategy: focus on preventing the consumer's problem as a result of purchasing the brand, the ability to bring joy to the consumer, stimulation of the purchase, minimization of the risk from the purchase. The decision is made depending on which quadrant of the matrix the product or service belongs to. Depending on the characteristics of communication strategies and purchase motivation, the authors have systematized digital marketing communications tools (Table 1). 
Table 1. Systematization of digital marketing communication tools according to the Rossiter-Percy method.

\begin{tabular}{|c|c|c|}
\hline & Information motivation (affects the mind) & $\begin{array}{l}\text { Transformational motivation } \\
\text { (affects feelings) }\end{array}$ \\
\hline $\begin{array}{l}\text { Low involvement } \\
\text { (buying decision is usually } \\
\text { made easily) }\end{array}$ & $\begin{array}{l}\text { Low-risk purchases when it is needed. } \\
\text { - Display advertising : banners and teasers } \\
\text { - Contextual advertising and search engine } \\
\text { optimization of the site } \\
\text { - News articles online portals } \\
\text { - Corporate website and SMM } \\
\text { - Promotion of online sales }\end{array}$ & $\begin{array}{l}\text { Low Risk Shopping, "reward", that is, } \\
\text { without absolute necessity, "for the } \\
\text { soul." } \\
\text { - Mobile applications } \\
\text { - Videohostings } \\
\text { - SMM } \\
\text { - Messages with news function }\end{array}$ \\
\hline $\begin{array}{c}\text { High involvement } \\
\text { (purchase decision usually } \\
\text { preceded by long } \\
\text { reflection and inner fight) }\end{array}$ & $\begin{array}{c}\text { High-risk purchases, if necessary. } \\
\text { - E- mail newsletters aimed at building } \\
\text { relationships } \\
\text { - Search engine optimization } \\
\text { - Corporate website } \\
\text { - Communication with educational function }\end{array}$ & $\begin{array}{c}\text { High-risk purchases, "rewards". } \\
\text { - SMM } \\
\text { - Text advertising } \\
\text { - Direct advertising communication } \\
\text { - Information articles on industry's social } \\
\text { platforms }\end{array}$ \\
\hline
\end{tabular}

\section{RESULTS AND DISCUSSION}

The method proposed by the authors was tested for the bread-baking complex Vseslav. On the bakery market in the Sverdlovsk region there are 32 large and mediumsized bread-baking complexes, 26 enterprises of the Regional Consumer Union, about 200 mini-bakeries. In addition, many large retail chains and catering enterprises tend to have their own bakery production [12]. The market for bread and bakery products in the Sverdlovsk region is low-concentrated. This means that it is characterized by strong competition, the lack of barriers to entry and exit, as well as the weak market power of enterprises. Accordingly, the market competition for the consumer is possible either at the expense of price policy, or at the expense of other additional advantages. The major players on the market are Vseslav, SMAK and REZHLEB. In the course of the study, the authors conducted a survey to assess the recognition of these brands. The participants were random users of the social network VKontakte in the amount of 90 people. They were asked to answer the question of whether they are familiar with the products of the Vseslav, SMAK and REZHHLEB brands. According to the results of the survey, the most recognizable trade mark in the bread and bakery market of the Sverdlovsk region is SMAK, Vseslav has the lowest rating. Speaking about the target audience, it is worth noting that bread and bakery products are products of daily demand and they are consumed by almost the entire population. The consumer survey conducted by the authors showed that the key criterion of choosing bread is its quality, as well as flour variety, freshness and taste (Table 2).

At the first stage of developing a communication strategy, it can be concluded that the reasons that encourage the consumer to make a purchase of bread (motivation) are the purchase of a high-quality product for a daily diet, the prerequisites for deciding on the purchase (involvement) - the recognition of the producer. therefore, the emphasis on the quality of bakery products and increasing the level of recognition are target indicators of the communication strategy of the vseslav brand. in order to determine the general principles of positioning bakery products on the market, an analysis of the information message and selected communication channels of competitors was carried out. in general, it can be noted that all companies focus the attention of the consumer on the composition of their products. a comparative analysis of the used types of marketing communication tools showed that manufacturers of bread and bakery products communicate with consumers through the maintenance of corporate sites, social networks and the publication of news in the internet media. sales incentives are represented by discounts and promotions in various retail chains. the result of the second stage is the development of the bread-baking complex vseslav unique selling proposition. the usp should emphasis not only on the quality and natural composition of bread, but also on the taste and adherence to the traditions of bread consumption in russian society: "high-quality bread from natural ingredients: towards the taste and without changing traditions." the rossiter-percy matrix method defined the strategy of informational lowinvolvement pr as optimal for a given type of product (table 3), since this is the case when the purchase decision is made by the consumer easily and quickly to solve the problem.

The selection of communication channels for the transmission of the USP to the target audience as part of the implementation of the strategy of informational lowinvolvement promotion is presented in Table 4.

The selected strategy implies that the content of communications should demonstrate the possibility of solving the problem. In this case the problem is buying high-quality bread, which will satisfy hunger without undesirable consequences for health, provide the necessary information and arguments, convince the consumer, and guarantee the reliability of the bread manufacturer. The complex of marketing communications developed by the authors is aimed at 
Table 2. Criteria for the selection of products in the bread and bakery market by the end consumer.

\begin{tabular}{|c|c|c|}
\hline Criteria & $\%$ of the number of respondents & $\begin{array}{c}\text { of the number of } \\
\text { responses }\end{array}$ \\
\hline Quality & 43 & 74.1 \\
\hline Variety & 20.8 & 35.8 \\
\hline Freshness & 17.6 & 30.3 \\
\hline Taste & 6.2 & 11 \\
\hline Price & 6.1 & 10.6 \\
\hline Softness & 3.3 & 5.8 \\
\hline Appearance, including packaging & 3 & 5.1 \\
\hline Total & 100 & \\
\hline
\end{tabular}

Table 3. Selecting a Communication Strategy Based on the Rossiter-Percy Matrix Method.

\begin{tabular}{|c|c|c|c|}
\cline { 3 - 4 } \multicolumn{2}{c|}{} & Information motivation & $\begin{array}{c}\text { Transformational } \\
\text { motivation }\end{array}$ \\
\cline { 3 - 4 } \multicolumn{2}{c|}{} & $\begin{array}{c}\text { 1) Bread is a product of the daily diet } \\
\text { 2) Bread makes a meal more satisfying } \\
=>\text { buying as needed }\end{array}$ & - \\
\hline Low involvement & $\begin{array}{c}\text { 1) Minimal economic risk } \\
\text { 2) Brand awareness } \\
\text { a the decision to buy is } \\
\text { made easily }\end{array}$ & $\begin{array}{c}\text { Informational low-involvement } \\
\text { promotion: } \\
\text { - contextual advertising, SEO } \\
\text { - contests on social media } \\
\text { - articles about products on internet } \\
\text { portals }\end{array}$ & $\begin{array}{c}\text { Transformational } \\
\text { low-involvement } \\
\text { promotion }\end{array}$ \\
\hline High involvement & - & Information highly involved promotion & $\begin{array}{c}\text { Transformational highly } \\
\text { involved advancement }\end{array}$ \\
\hline
\end{tabular}

Table 4. Set of digital marketing communications tools and characteristics of Vseslav brand.

\begin{tabular}{|c|c|}
\hline Tool & Description \\
\hline \multicolumn{2}{|r|}{ Sales promotion } \\
\hline Price stimulation & Promotions and discounts \\
\hline Involvment stimulation & Running social media contests on VKontakte network \\
\hline \multicolumn{2}{|r|}{ Advertising } \\
\hline Display advertising & Placing banners and teasers on thematic and popular portals \\
\hline Internet advertising & Contextual advertising and search engine optimization ( SEO ) \\
\hline \multicolumn{2}{|r|}{ PR } \\
\hline Media relations & $\begin{array}{c}\text { News articles about products on various Internet portals: E1, Yekaterinburg.rf, } \\
\text { justmedia.ru, ura.news, ekb.dk.ru and others }\end{array}$ \\
\hline Participation in events & $\begin{array}{l}\text { Information about participation and victories in industry competitions on the website } \\
\text { and industry's social platforms }\end{array}$ \\
\hline Corporate website and SMM & $\begin{array}{l}\text { Publication of news and articles about products, posting of recipes that include Vseslav } \\
\text { products }\end{array}$ \\
\hline
\end{tabular}

forming a positive image of the Vseslav brand, which, in turn, contributes to building trusting relationships with its target audience.

\section{CONCLUSION}

The results of the study showed that the development of a communication strategy based on the characteristics of motivation and consumer involvement in the process of making a purchase decision provides an opportunity to choose those digital communication tools that make it possible to convey a unique selling preposition to the consumer as efficiently as possible, and form feedback channels with the target audience. The complex of digital marketing communications, developed on the basis of the Rossiter-Percy matrix method, assumes that the company objectively assesses its real capabilities, behavioral characteristics of the competitors and the consumers, is ready to develop and improve its communication policy. The results of the authors' research and their approbation on the example of the bread-baking complex Vseslav showed that among the tools of the complex of marketing communications on the bakery market, it is recommended to use media advertising, sales promotion and PR. Incentives from everyday life help attracting potential consumers and convey information about products to them, as well as increase the loyalty of existing buyers. Advertising, in addition to attracting new consumers, expand brand awareness, and PR forms a positive image, which, in turn, contributes to building trusting relationships, and therefore effective communication with the target audience. The use of digital communication tools will increase the 
effectiveness of marketing activities by escalating the effectiveness of the information message.

The authors consider the study of methods for assessing the effectiveness of a communication strategy implemented by an enterprise as a further direction of research.

\section{AUTHORS' CONTRIBUTIONS}

K.E. and E.M. collected the data. N.I. conceived designed the analysis. L.K. performed the analysis. N.I., E.M wrote the paper. All authors have read and agreed to the published version of the manuscript.

\section{REFERENCES}

[1] J. Gburova, R. Bacik, Classical and Modern Forms of Marketing Communication in Selected Services, In: 34th International-Business-InformationManagement-Association (IBIMA) Conference Volume, 2019 pp. 7971-7977.

[2] P. K. Kannan, L. Hongshuang, Digital marketing: A framework, review and research agenda. International Journal of Research in Marketing, 34(1) (2016) pp. 22 - 45. DOI: https://doi.org/10.10 16/j.ijresmar.2016.11.006.

[3] M.A. Simakina, Modern marketing communication s: monograph. Publishing house of the Moscow University for the Humanities, 2019 p. 160.

[4] J. Landrevi, J. Levy, D. Lyndon, Mercator. Marketing theory and practice. MCFER, $2006 \mathrm{p}$. 664.

[5] N. Granados, A. Gupta, R.J. Kauffman, Online and offline demand and price elasticities: Evidence from the air travel industry. Information Systems Research, 2012 pp. 164-181. DOI: https://doi.org/10.2307/23207879.

[6] A. Kusa, A. Zauskova, L. Cabyova, Effect of marketing communication on consumer preferences and purchasing decisions. Ad Alta-journal Of Interdisciplinary Research, 10 (2020) pp. 150-155.

[7] K. Xu, J. Chan, A. Ghose, S. Han, Battle of the channels: The impact of tablets on digital commerce. Management Science, 2016 pp. 1469 - 1492. DOI: https://doi.org/10.1287/mnsc.20 15.2406 .

[8] L.M. Kapustina, I.D. Mosunov, T.L. Sysoeva, Tools for promoting a brand on the Internet: selection algorithm. Marketing and marketing research, 2015 pp. 104 - 112. DOI: https://doi.rg/10.18334/rp .19.12.39690.
[9] B.J. Bronnenberg, B.J. Kim, C.F. Mela, Zooming in on choice: How do consumers search for cameras online? Marketing Science, 2016 pp. 693-712. DOI: https://doi.org/10.1287/mksc.2016.0977.

[10] M.A. Kravets, Communicative strategy: systematization of definitions, approaches to development. Bulletin of the Voronezh State University, 2013 pp. 149-153.

[11] J.L. Rossiter., L. Percy, Advertising and promotion of goods, 2000 pp. 156-189.

[12] Market structure of manufacturers of bakery products in the Sverdlovsk region for 2020. http://urbc.ru/. 